\title{
Taxonomic notes on the Macrocheilus Hope (Coleoptera, Carabidae, Helluonini) from Oriental Region, with description of one new species from the Philippines
}

\author{
Danyang Zhao ${ }^{1,2, \dagger}$, Mingyi Tian ${ }^{2, \ddagger}$ \\ I Guangdong Academy of Forestry, Guangzhou, Guangdong 510520, China 2 Department of Entomology, \\ College of Natural Resources and Environment, South China Agricultural University, Guangzhou, Guangdong \\ 510640, China \\ † urn:lsid:zoobank.org:author:BA11DAFD-ECCC-4085-B9BA-4D33B575EACB \\ †urn:lsid:zoobank.org:author:1EA26700-CA72-4703-B5FB-ED96F8F1A101 \\ Corresponding author: Mingyi Tian (mytian168@yahoo.com.cn)
}

Academic editor: Terry Erwin | Received 17 May 2012 | Accepted 16 July 2012 | Published 18 October 2012

urn:lsid:zoobank.org:pub:76973A68-EEE6-4C43-ACE8-1573BB6964C3

Citation: Zhao D, Tian M (2012) Taxonomic notes on the Macrocheilus Hope (Coleoptera, Carabidae, Helluonini) from Oriental Region, with description of one new species from the Philippines. ZooKeys 228: 77-100. doi: 10.3897/ zookeys.228.3401

\begin{abstract}
Taxonomic notes, together with illustrated characters, on the oriental species of the genus Macrocheilus Hope, 1838 (Carabidae, Helluonini) are provided. One new species, Macrocheilus deuvie sp. n. is described from the Philippines. A key to all species of Macrocheilus in the Oriental Region is also provided.
\end{abstract}

\section{Keywords}

Coleoptera, Carabidae, Helluonini, Macrocheilus, Oriental Region, new species

\section{Introduction}

The genus Macrocheilus Hope, 1838 is composed of Oriental, Palaearctic and Ethiopian species (Csiki 1932, Reichardt 1974). In total, fifty-six species of the genus are reported, among them, thirty-five species in the Ethiopian Region, nineteen in Oriental Region, and only two in Palaearctic Region (Lorenz 2005, Hůrka 2003, Zhao and Tian 2010).

Copyright Danyang Zhao, Mingyi Tian. This is an open access article distributed under the terms of the Creative Commons Attribution License 3.0 (CC-BY), which permits unrestricted use, distribution, and reproduction in any medium, provided the original author and source are credited. 
For the Oriental Macrocheilus, Heller (1900) gave a table of ten species. But of them, two (dorsalis Klug and scapularis Klug) are actually African species, one (distactus Wiedemann) belongs to the genus Creagris, and one (tripustulatus Fairmaire) is a species of Pheropsophus. Andrewes (1920) dealt with ten Oriental species of the genus. Jedlička (1963) treated the East Asian Macrocheilus species and mentioned only five species. Park et al. (2006) listed six species from Vietnam. Zhao and Tian (2010) described seven new species and gave a key to Chinese species.

The aim of this paper is to provide taxonomic notes on all Oriental species of Macrocheilus by means of checking most of the type materials and a few other materials. As a result of the study, the examined materials are preserved in the Museum National d'Histoire Naturelle, Paris, France (MNHN). One new species of Macrocheilus from the Philippines is described. In addition, a distribution map of the genus in the Oriental Region is provided.

\section{Materials and methods}

Materials for this study were dry mounted specimens. Dissection of specimens was done following the standard technique described by Lindroth (1974). Observations and measurements were made under stereo microscope (Leica, MZ125) and ocular microscope (Wild M5).

Abbreviations for the collections in which the type materials are deposited as follows:

\begin{tabular}{ll} 
LMN & Leiden Museum, the Netherlands \\
MDSG & Museum Dresden, Saxony, Germany \\
MGI & Museum Genoa, Italy \\
MNHN & Museum National d'Histoire Naturelle, Paris, France \\
NHML & Natural History Museum, London, the U.K. \\
NMP & National Museum Prague, Czech Republic \\
SCAU & South China Agricultural University, Guangzhou, China \\
SNSD & Staatliches Naturhist. Sammlungen Museum für Tierkund, Dresden, \\
\multicolumn{2}{c}{ Germany }
\end{tabular}

ZMUC Zoological Museum University of Copenhagen, Copenhagen, Denmark

\section{Taxonomic treatment}

Genus Macrocheilus Hope, 1838

http://species-id.net/wiki/Macrocheilus

Macrocheilus Hope, 1838: 166. Type species: Macrocheilus bensoni Hope, 1838. Jeannel, 1949: 1041. Zhao \& Tian, 2010:4.

Acanthogenius Reiche, 1842: 334. Type species: Helluo impictus Wiedemann, 1823. 
Generic diagnosis. Medium sized (length from 8.0 to $17.0 \mathrm{~mm}$ ), elongate, whole body coarsely punctuate and pubescent, except for labrum and middle region of ventral side of head. Head with two supraorbital setae on each side; ligula fairly wide, deeply impressed beneath at sides of base; mentum deeply emarginated, with a long and slender tooth; palpi varied in form; labrum extraordinarily or well developed; mandibles dorsally covered by labrum or not covered; antennae stout and flat, densely pubescent from antennomere 5. Pronotum truncate-cordiform or quadrate, basal margin more or less produced backwards in middle; lateral margin with two setae, one just before middle, and the other at hind angle. Elytra with deep striae and setiferous pores; intervals slightly or rather convex, interval 8 usually wide. Metepisterna elongate and very narrow in all species. Tarsomere 4 emarginate. Wings fully developed. No externally visible sexual dimorphic characters present. Median lobe of aedeagus varied in form. Parameres of aedeagus quite similar, elongate, the left one larger than the right one.

Differences with other genera of Helluonini in the Oriental Region. Macrocheilus spp., with larger body size, simple $4^{\text {th }}$ tarsomeres, and non-securiform labial palpomere are distinctly different from Colfax spp. (smaller body size, securiform labial palpomere) and Creagris spp. (bilobed $4^{\text {th }}$ tarsomere; smaller body size). Functional wings and the occurrence of a long spiniform median tooth of mentum of Macrocheilus distinguish them from Omphra spp. (which are brachypterous and have a short median tooth of the mentum).

Generic range. Oriental Region (China, Vietnam, Laos, Cambodia, Myanmar, India, Sri Lanka, the Philippines, Malaysia and Indonesia), Palaearctic Region (Pakistan, Syria, Asia Minor), Ethiopian Region (Ethiopia, Tanzania, Uganda, Senegal, Guinea, Guinea-Bissau, Sierra Leone, Togo, Nigeria, Central Africa, Cameroon, Gabon, Congo, Zimbabwe, Angola, South Africa, Madagascar).

\section{Key to species of Oriental Macrocheilus}

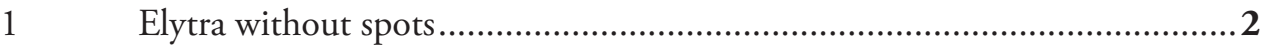

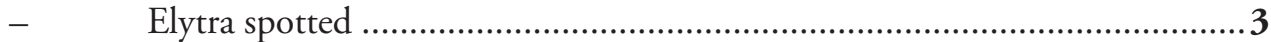

2 Head and pronotum red; ligula with apical outer angles rounded; apex of lateral lobes of mentum fairly acute (Fig. 9); labrum with apical margin not sinuate (Fig. 1). Length $6.5 \mathrm{~mm}$ M. bicolor Andrewes

- Whole body piceous; ligula with apical outer angles rectangular; apex of lateral lobes of mentum rounded (Fig. 10); labrum with apical margin plurisinuate (Fig. 2). Length $15.0 \mathrm{~mm}$........................... impictus (Wiedemann)

3 Maxillary palpomere 4 not flattened and dilated, lateral lobes of mentum rounded on outer margin, mandibles not exposed, lateral margin of labrum rounded, front margin of clypeus not or slightly emarginate in middle, elytron with one or two spots............................................................................... 4

- Maxillary palpomere 4 strongly flattened and dilated, lateral lobes of mentum sinuate behind middle or on anterior one-third, mandibles exposed, lateral margin of labrum distinctly sinuate on anterior one-third, front margin of clypeus deeply and widely emarginate in middle, elytron with one spot....16 
Labrum with anterior setae distinctly on upper surface margin

Labrum with anterior setae close to or on the apical margin.

Labrum with apex narrow (Fig. 3); mentum with median tooth stout and wide, strongly sinuate at middle of lateral margins (Fig. 11). Length 25.0 $\mathrm{mm}$

M. immanis Andrewes

Labrum with apex wide; mentum with median tooth slender, almost straight at sides

Elytral spot transverse and almost rectangular (Fig. 46); median tooth of mentum with four or five setae (Fig. 12). Length $16.0 \mathrm{~mm}$

M. niger Andrewes

Elytral spot cruciform (Fig. 47); median tooth of mentum with two setae. Length $14.5 \mathrm{~mm}$

M. asteriscus (White)

Elytral spot rounded, maxillary palpomere 4 roundly elongate; anterior setae of labrum close to apical margin. Length $12.5-14.0 \mathrm{~mm}$

M. vitalisi Andrewes

Elytral spot oblong, maxillary palpomere 4 short and stout (Fig. 21); anterior setae of labrum along or on apical margin

Elytral spot covering intervals 3-7, anterior seta of labrum on apical margin (Fig. 5). Length $13.0 \mathrm{~mm}$ M. binotatus Andrewes Elytral spot covering intervals $2-7$, anterior seta of labrum along apical margin. Length $10.0 \mathrm{~mm}$ M. macromaculatus Louwerens Labrum with anterior setae on apical margin; ligula thickened at apex..... 11 Labrum with anterior setae beneath apex; ligula thin at apex..... 13 Labrum with apex wide; mentum with median tooth sinuate near apex on lateral margin, lateral lobes obtuse at apex. Length 15.5-17.0 mm

M. gigas Zhao \& Tian Labrum with apex pointed; mentum with median tooth not sinuate on lateral margin, lateral lobes sharp at apex Body length 11.7-11.0 mm; elytral spots smaller (Fig. 51); labrum exceptionaly convex on anterior portion which results apex can not be seen; maxillary palpomere 4 strongly and roundly dilated on anterior half portion.

M. parvimaculatus Zhao \& Tian

Body length 12.0-12.5 mm; elytral spots larger (Fig. 52); labrum normally convex, apex visible (Fig. 6); maxillary palpomere 4 slightly dilated (Fig. 22) Head and pronotum reddish brown (Fig. 53); labrum relatively long; pronotum elongate; tibiae testaceous. Length $8.4 \mathrm{~mm} . . .$. M. chaudoiri Andrewes Head and pronotum black; labrum short (Fig. 7); pronotum wide; tibiae black. Length $8.0 \mathrm{~mm}$ 
15 Maxillary palpomere 4 slightly dilated; labrum not recurved at apex; clypeus with irregular setae on middle. Length $15.0 \mathrm{~mm}$.................. bensoni Hope

- $\quad$ Maxillary palpomere 4 not dilated (Fig. 24); labrum curved at anterior part (Fig. 8); clypeus almost glabrous on middle. Length $9.5 \mathrm{~mm}$...........M. deuvie sp. n.

16 Elytral spots large $(1.5-2.2 \mathrm{~mm})$, nearly rectangular .............................. 17

- $\quad$ Elytral spots small $(1.3-1.4 \mathrm{~mm})$, not rectangular................................... 19

17 Color brown; labrum with only three pairs of labral setae, apex pointed rounded; mandibles obtuse at apices; median tooth of mentum with lateral margin not sinuate. Length $10.8 \mathrm{~mm}$

M. fuscipennis Zhao \& Tian

- $\quad$ Color black; labrum with four pairs of labral setae, apex widely rounded; mandibles sharp at apices; median tooth of mentum with lateral margin sinu-

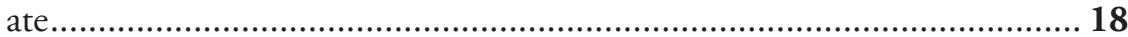

18 Labrum with additional setae located between the anterior and intermediate setae (Fig. 8 in Zhao \& Tian, 2010); median tooth of mentum with lateral margin sinuate in middle; mandibles less sharp at apices. Length 12.3-12.5 $\mathrm{mm}$.............................................................. solidipalpis Zhao \& Tian

- $\quad$ Labrum with additional setae located before the anterior setae (Fig. 9 in Zhao \& Tian, 2010); median tooth of mentum with lateral margin sinuate on anterior one-third; mandibles sharper at apices. Length $11.0 \mathrm{~mm}$

M. cheni Zhao \& Tian

19 Labrum with anterior and intermediate setae distance from each other, apex pointed rounded (Fig. 10 in Zhao \& Tian, 2010); mandibles sharp at apices; median tooth of mentum sharp at apex; pronotum almost quadrate. Length $12.1 \mathrm{~mm}$

M. quadratus Zhao \& Tian

- $\quad$ Labrum with anterior and intermediate setae closed each other, apex widely rounded (Fig. 11 in Zhao \& Tian, 2010); mandibles obtuse at apices; median tooth of mentum strongly obtuse at apex; pronotum nearly cordiform. Length $11.7 \mathrm{~mm}$ M. sinuatilabris Zhao \& Tian

\section{Macrocheilus bicolor Andrewes, 1920}

http://species-id.net/wiki/Macrocheilus_bicolor

Figs 1, 9, 17, 37, 43

Macrocheilus bicolor Andrewes, 1920: 503; Andrewes, 1930: 206; Csiki, 1932: 1573; Lorenz, 2005: 512. Type locality: India (Bombay: Belgaum), deposited in NHML.

Diagnosis. Length $6.3-6.5 \mathrm{~mm}$, width $2.5 \mathrm{~mm}$. Head and prothorax red; elytra black or sometimes bluish black. Labrum (Fig. 1) semicircular in front, shortly depressed towards base, front pair of setae small and closely placed along the front margin, intermediate one at a distance from margin; ligula rectangular, with a wide and deep median impression, a pair of setae at a distance form apex depressed at base; apex truncate, outer apical angles rounded; mentum (Fig. 9) glabrous at base, 


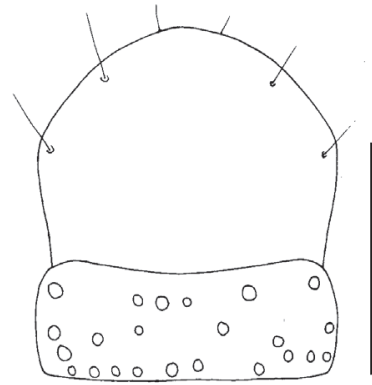

1

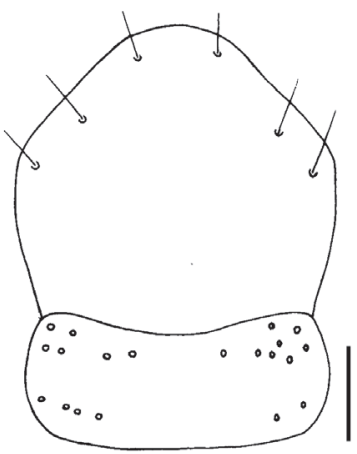

4

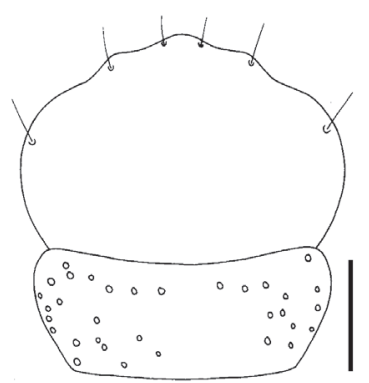

2

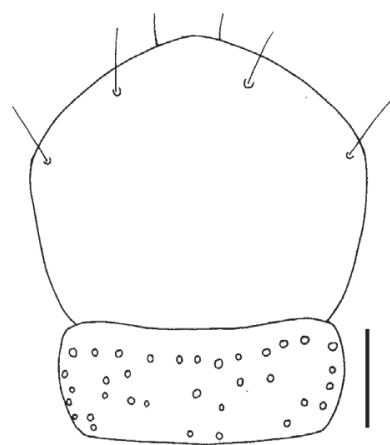

5

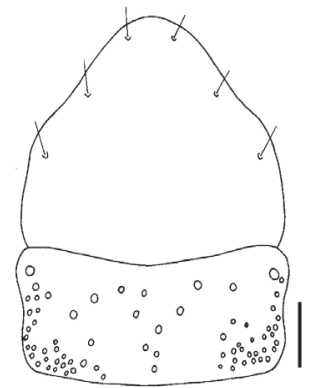

3

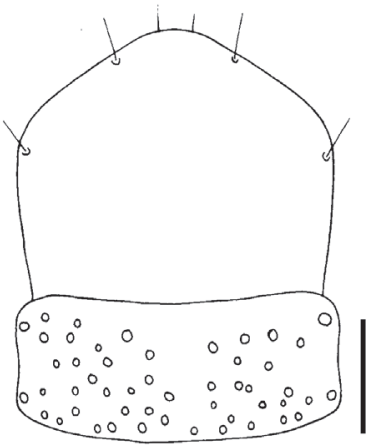

6

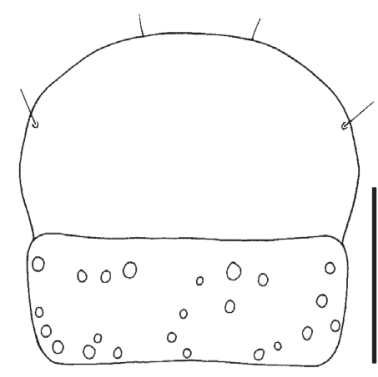

7

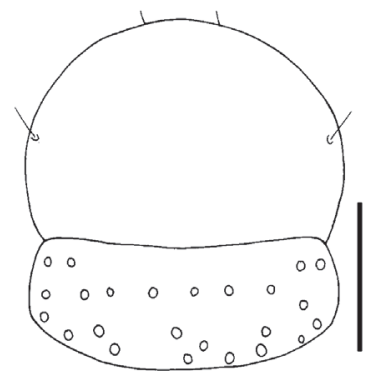

8

Figures I-8. Labrum and clypeus of Macrocheilus (dorsal view): I M. bicolor (holotype) $\mathbf{2}$ M. impictus (male) $3 \mathrm{M}$. immanis (holotype) $4 \mathrm{M}$. niger (holotype) $5 \mathrm{M}$. binotatus (female) $6 \mathrm{M}$. tripustulatus (holotype) $7 \mathrm{M}$. nigrotibialis (holotype) $8 \mathrm{M}$. deuvie (holotype). Scale bar: $0.5 \mathrm{~mm}$.

both tooth and lobes elongate, slender and sharp at apex; tooth almost as long as lobes, two pairs of setae on base; lobes sinuate at a distance from apex along outer margin; maxillary palpi (Fig. 17) not dilated. Elytra without spots.

Female genitalia. Gonocoxite short, stout, inner margin arcuate and not sinuate, apex short and sharp (Fig. 37). 


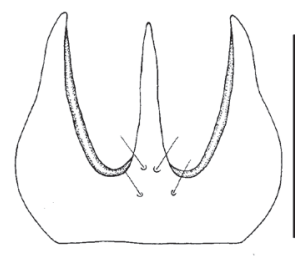

9

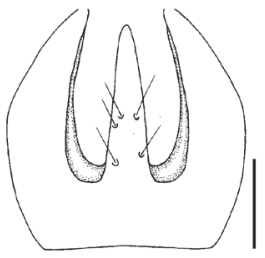

13

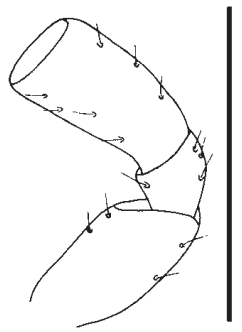

17

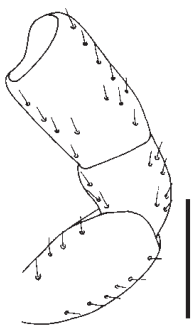

21

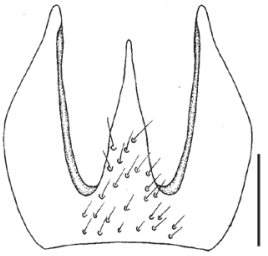

10

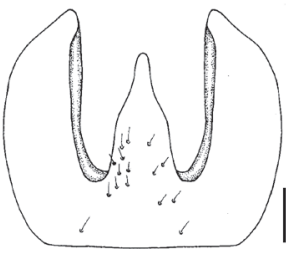

11

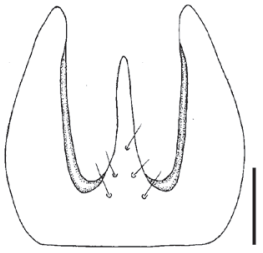

12

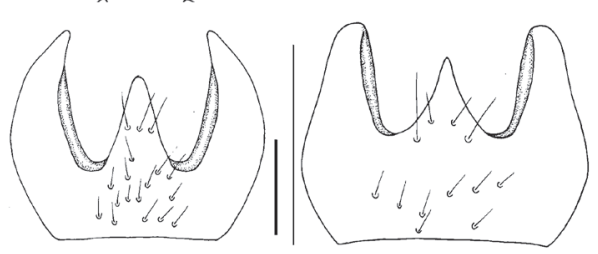

14

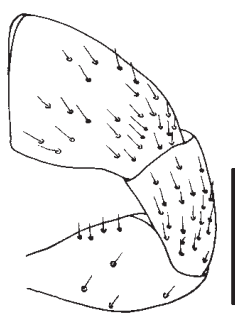

18
15

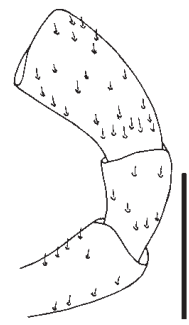

19

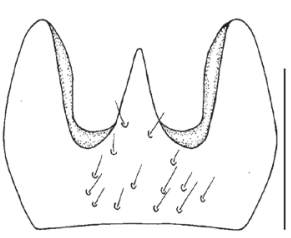

16

20

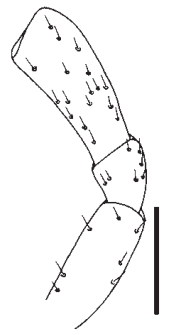

22

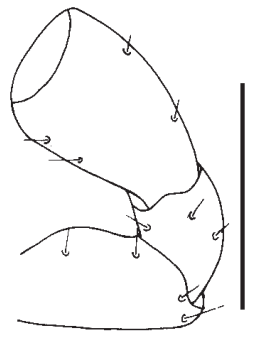

23

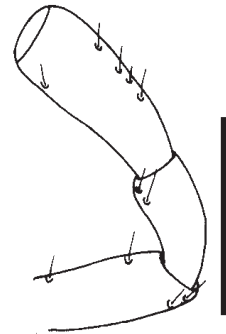

24

Figures 9-24. Mentum and Left maxillary palpi of Macrocheilus (ventral view): 9, 17 M. bicolor (holotype) I0, $\mathbf{8} \mathrm{M}$. impictus (male) II, $\mathbf{1 9} \mathrm{M}$. immanis (holotype) I 2, $20 \mathrm{M}$. niger (holotype) I3, $\mathbf{2} \mathbf{I}$. binotatus (female) 14, 22 M. tripustulatus (holotype) 15, 23 M. nigrotibialis (holotype) 16, 24 M. deuvie (holotype). Scale bar: $0.5 \mathrm{~mm}$.

Remarks. This species is allied to the next species, M. impictus (Wiedemann). Both differ from other species in the absence of elytral spot.

Materials examined. Holotype: 1 female, labeled "Kaoeqaoe, 740, Type, Macrochilus bicolor Type Andr., H. E. Andrewes det.; H. E. Andrewes Coll. B. M. 1945-97.; 
Macrochilus bicolor Andrewes, 1920", deposited in NHML. 1 ex, sex unknown (the abdomen missing), labeled "Bangalore, Chikkangalur, Taboourel, 1900; Macrocheilus bicolor Andrewes, H. E. Andrewes det.", deposited in MNHN.

Distribution. India.

\section{Macrocheilus impictus (Wiedemann, 1823)}

http://species-id.net/wiki/Macrocheilus_impictus

Figs $2,10,18,25,26,38,44$

Helluo impictus Wiedemann, 1823: 49. Dejean, 1825: 287; Reiche, 1842: 335; Heller, 1900: 3; Andrewes, 1920: 503; 1921: 168; Csiki, 1932: 1574; Lorenz, 2005: 512. Type locality: India, deposited in ZMUC.

Diagnosis. Length $14.5-15.0 \mathrm{~mm}$, width 5.0-5.5 mm. Black. Labrum (Fig. 2) with front margin rounded and bisinuate, three pairs of setae close to margin, and front two pairs on sinuated area; mandibles slightly obtuse at apex; mentum (Fig. 10) irregularly setose in basal half, both tooth and lobes elongate and sharp at apex, tooth slightly shorter than lobes; maxillary palpomere 4 (Fig. 18) cylindrical and gradually dilated toward apex, rounded and obliquely truncate at apex. Elytra without spots.

Male genitalia. Median lobe dilated on dorsal side in middle partion, sinuate on ventral side; apical lamella elongate, not sinuate near apex, rounded at apex (Figs 25-26).

Female genitalia. Gonocoxite slender, five setae on dorsal surface, sharp at apex (Fig. 38).

Remarks. Similar to M. bicolor without elytral spots, distinctly differs by larger size, body black, sinuate front margin of labrum and plurisetose mental tooth.

Materials examined. 1 male, labeled "Indes Orientales, $\mathrm{M}^{\text {ts }}$ Kodeicanel, J. Castets 1886"; 1 male, "India, Bangalore. P.S. Nathan, 1936"; 1 male, "Punjab Baddia (Indes Angl.); G. Babault Avril 1914"; 1 male, "S. India, Medungadu, P.S. Nathan. 1936"; 3 males, "Java", "Ex-Musaeo Chaudoir from Coll. Dejean"; 1 female, "Java", "ExMusaeo Mniszech from Coll. Dejean”. All deposited in MNHN.

Distribution. India (East India) and Indonesia (Java).

\section{Macrocheilus immanis Andrewes, 1920}

http://species-id.net/wiki/Macrocheilus_immanis

Figs 3, 11, 19, 27, 28, 45

Macrocheilus immanis Andrewes, 1920: 498. Csiki, 1932: 1574; Jedlička, 1963: 469;

Lorenz, 2005: 512. Type locality: Myanmar (Taung-ngu), deposited in NHML.

Diagnosis. Length $24.7 \mathrm{~mm}$, width $8.3 \mathrm{~mm}$. Labrum (Fig. 3) elongate, three pairs of equidistant setae on upper surface near margin; ligula thickened, apex slightly 


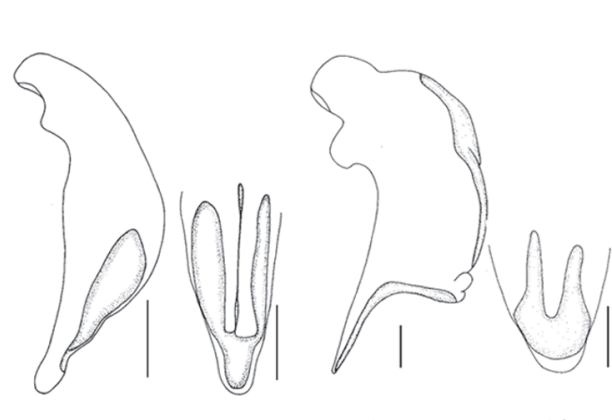

25

26

27

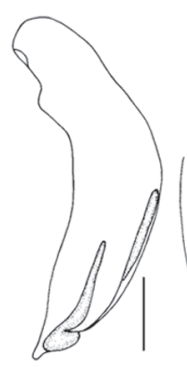

29

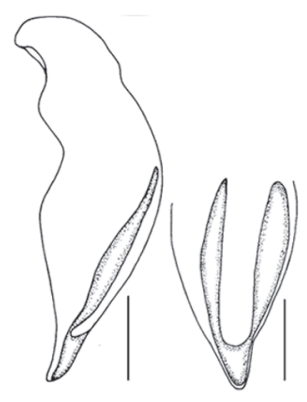

32

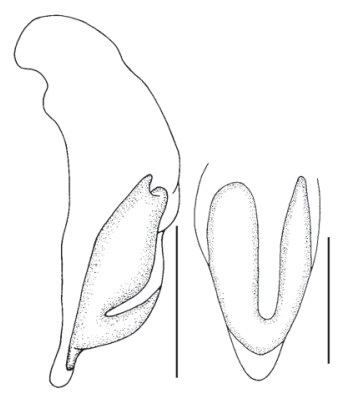

33

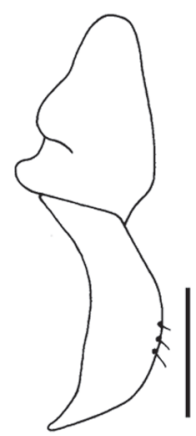

39

34
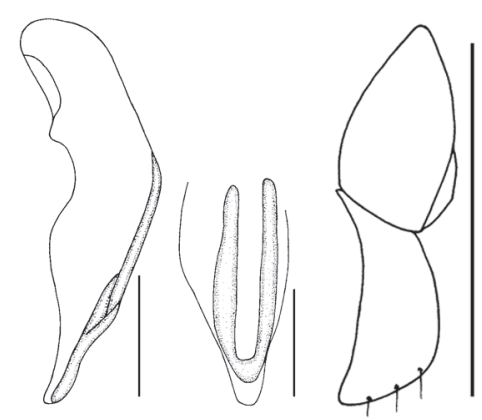

37

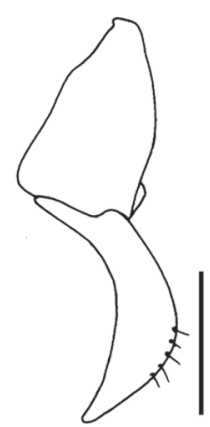

38

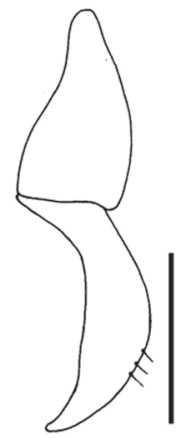

40

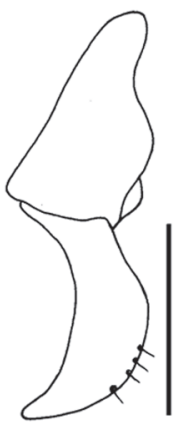

41

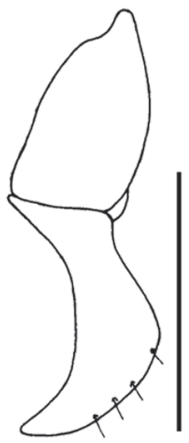

42

Figures 25-42. Aedeagus of Macrocheilus (left lateral and dorsal view) and Left gonopods of female genitalia (dorsal view): 25, 26, 38 M. impictus 27, 28 M. immanis (holotype) 29, 30, 39 M. niger 31 , 32, 4 I M. tripustulatus 33, 34, $42 \mathrm{M}$. nigrotibialis (holotype) 35, $36 \mathrm{M}$. deuvie (holotype) $37 \mathrm{M}$. bicolor (holotype) $\mathbf{4 0}$ M. binotatus. Scale bar: $0.5 \mathrm{~mm}$.

narrowed, slightly emarginate in middle of front margin, deeply depressed near apex to form a median channel, with five pairs of setae along sides, hollowed out above with a median carina; mentum (Fig. 11) with both tooth and lobes stout, tooth shorter than lobes, contracted after middle, irregularly setose on ventral surface on basal half; maxillary palpomere 4 (Fig. 19) dilated, densely setose; labial 

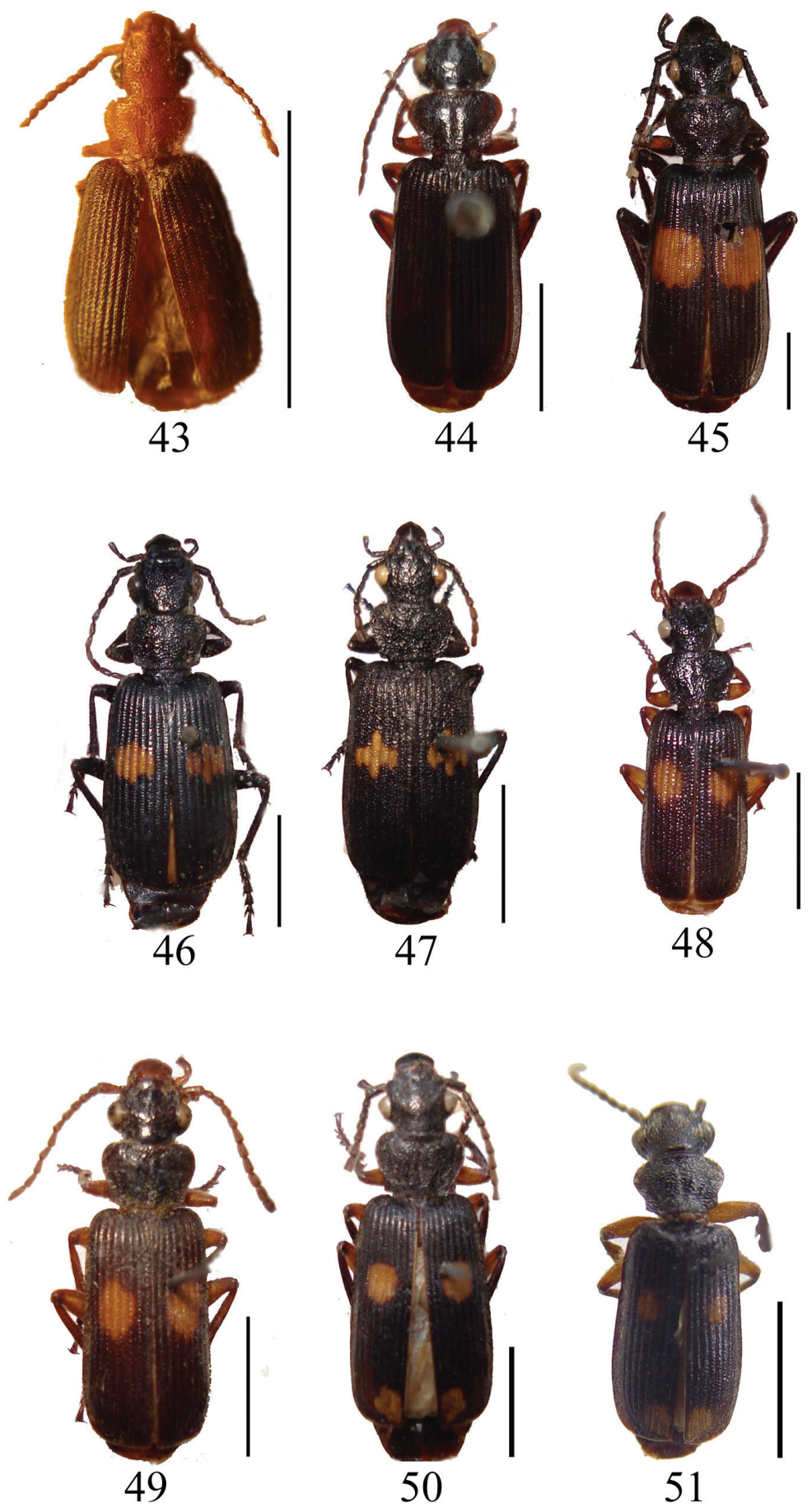

Figures 43-5 I. Habiti of Macrocheilus (dorsal view): 43 M. bicolor (holotype) 44 M. impictus (male) $45 \mathrm{M}$. immanis (holotype) $46 \mathrm{M}$. niger (holotype) $47 \mathrm{M}$. asteriscus (male) $48 \mathrm{M}$. vitalisi (holotype) $49 \mathrm{M}$. binotatus (female) $\mathbf{5 0}$ M. gigas (holotype) $\mathbf{5}$ I M. parvimaculatus (holotype). 
palpomere 4 dilated, palpomere 3 not dilated inwards. Elytal spots nearly square, large, near the middle, cover intervals 2-7.

Male genitalia. Median lobe of aedeagus strongly dilated and stout, strongly sinuate near paramere, straight towards apex, apical lamera elongate and narrowed at apex (Figs 27-28).

Remarks. This species is similar to $M$. niger and $M$. asteriscus in having anterior setae of labrum obviously on upper surface, but differs from the other two species by the large and almost square elytral spots and stout median tooth of mentum.

Materials examined. 1 male, the holotype, labeled "Toungoo; Type; Macrochilus immanis, Type, Andr., H. E. Andrewes det.; Macrochilus immanis Andrewes, 1920", deposited in NHML.

Distribution. Myanmar.

\section{Macrocheilus niger Andrewes, 1920}

http://species-id.net/wiki/Macrocheilus_niger

Figs 4, 12, 20, 29, 30, 39, 46

Macrocheilus niger Andrewes, 1920: 499. Csiki, 1932: 1574; Lorenz, 2005: 512. Type locality: India (Nilgiri Hills), deposited in NHML.

Diagnosis. Length 16.0-16.3 mm, width 6.0-6.2 mm. Labrum (Fig. 4) convex, with a short furrow on each side of base, narrowed and pointed in front, with three pairs of setae away from the margin; ligula thickened, apex truncate towards sides, apical margin slightly emarginate, deeply depressed towards base, with a small median impression near apex; mentum (Fig. 12) glabrous at base; median tooth shorter than lobes, rather narrow and with apex rather pointed, two pairs of setae at basal area; lateral lobes obtuse at apex. Palpi (Fig. 20) not dilated. Elytral spots transverse, close to the middle of interval 5, covering intervals 3-7.

Male genitalia. Median lobe stout, apical lamella short and round at apex (Figs 29-30).

Female genitalia. Gonocoxite subapically dilated, three setae on dorsal surface, sharp at apex (Fig. 39).

Remarks. Similar to $M$. asteriscus, but differs with the tooth of mentum plurisetose and elytral spot not cruciform.

Materials examined. 1 female, the holotype, labeled "type, 11, H. L. Andrewes, Nilgiri Hills, H. E. Andrewes Coll., B.M. 1945-97.; Macrochilus niger Type-, Andr., H. E. Andrewes det.; Macrochilus niger Andrewes, 1920", deposited in NHML. 1 male and 1 female, "Dehra-Dun 1940-45, Kumaon Himalaya, Liesenfeldt leg.", deposited in MNHN.

Distribution. India (Nilgiri Hills, Malabar, Madras and Bombay) and Sri Lanka. 


\section{Macrocheilus asteriscus White, 1844}

http://species-id.net/wiki/Macrocheilus_asteriscus

Fig. 47

Macrocheilus asteriscus White, 1844: 422; Bates, 1892: 389; Andrewes, 1919: 180; 1920: 500;1924: 470; 1930: 206; Csiki, 1932: 1573; Wu, 1937: 188; Jedlička, 1963: 470; Hůrka, 2003:407; Lorenz, 2005: 512; Zhao \& Tian, 2010: 6. Type locality: China (Hongkong), deposited in NHML.

Planetes crucifer Redtenbacher, 1867: 4. Type locality: China (Hongkong), deposited in NHML.

Remarks. M. asteriscus differs from other species in having cruciform elytral spots, the slender median tooth of mentum and the narrow apex of ligula.

Materials examined. 2 males, 1 female, "Hongkong" (MNHN); 2 males, "Hainan, Oct. 1979, Shaoming Zhuo leg." (SCAU); 2 males, "Guangdong: Zhanjiang, Jul. 1982" (SCAU); 1 male, 1 female, "Guangdong: Zhanjiang, May, 1983" (SCAU). 1 male, 1 female, "Annam, Phuc-Son, Nov. to Dec., H, Fruhstorfer", Central Vietnam (MNHN); 1 male, "Tonkin, P. Lemée, 1903-1906", North Vietnam (MNHN); 1 male, "Laos. Mouhot" and "Janson Acq. 1884" (MNHN); 2 males, "Java, Preanger", Indonesia (MNHN); 1 female, "Nilgherries" and "Ex. Musaeo H. W. Bates, 1892", India (MNHN).

Distribution. China, Vietnam, Laos, Myanmar, Indonesia and India.

\section{Macrocheilus vitalisi Andrewes, 1920}

http://species-id.net/wiki/Macrocheilus_vitalisi

Fig. 48

Macrocheilus vitalisi Andrewes, 1920: 500; Andrewes, 1930: 208; Csiki, 1932: 1575;

Wu, 1937:188; Jedlička, 1963: 470; Hůrka, 2003: 407; Lorenz, 2005: 512; Zhao \& Tian, 2010: 7.

Remarks. M. vitalisi is similar to M. binotatus from Sumatra, but as stated by Andrewes (1931), $M$. binotatus differs from $M$. vitalisi by "the dark colour, the elytral spot oblong and red; the upper surface generally is more coarsely and less densely punctuate, the genae are contracted more sharply to the neck, the sides of the prothorax are less sinuate behind, the elytral intervals more convex, with punctuation along the side more widely spaced and coarser". In addition, according to our examination, the anterior seta of the labrum is closer to the apical margin in M. vitalisi than in $M$. binotatus and the 4th maxillary palpomere is cylindrically dilated in M. vitalisi.

Materials examined. 1 female, the holotype, "China, Bowring 63.47*, 986 27/2/53" (NHML); 1 female, "Tonkin, Région de Hoa-Binh", "Muséum Paris, 1932, A. de Cooman" (MNHN).

Distribution. China, Laos, Vietnam, Borneo. 


\section{Macrocheilus binotatus Andrewes, 1931}

http://species-id.net/wiki/Macrocheilus_binotatus

Figs 5, 13, 21, 40, 49

Macrocheilus binotutats Andrewes, 1931: 68. Csiki, 1932: 1573; Lorenz, 2005: 512. Type locality: Indonesia (Sumatra), deposited in LMN.

Diagnosis. Length $14.0 \mathrm{~mm}$, width $4.8 \mathrm{~mm}$. Labrum (Fig. 5) with apex rounded and pointed, front setae on apical margin; mandibles covered by the labrum, sharp at apex; mentum (Fig. 13) glabrous at base, median tooth nearly as long as lobes, about five setae at basal half; maxillary palpomere 4 (Fig. 21) cylindrically dilated, labial palpomere 4 flat and dilated, labial palpomere 3 dilated inwards; ligula wide and rectangular, apical margin straight, with a wide median impression beneath apex, a seta on either side near apex. Elytral spots large and oblong, covering intervals $3-7$ in the middle.

Female genitalia. Gonocoxite elongate, three setae on dorsal margin, sparsely setose on ventral surface; apex sharp (Fig. 40).

Remarks. This species is similar to $M$. macromaculatus having elytral spots oblong; and it differs from $M$. macromaculatus in having the anterior setae of labrum on the apical margin.

Materials examined. 1 female, "Paggar Alam, Sumatra, J. Bouchaud", deposited in MNHN.

Distribution. Indonesia (Sumatra).

\section{Macrocheilus macromaculatus Louwerens, 1949}

http://species-id.net/wiki/Macrocheilus_macromaculatus

Macrocheilus macromaculatus Louwerens, 1949: 51. Lorenz, 2005: 512. Type Locality: Indonesia (Java), deposited in LMN.

Diagnosis. Length $10.0 \mathrm{~mm}$, width $3.0 \mathrm{~mm}$. Labrum large, semicircular anteriorly, with a flat depression on each sides, setae running along the sides in two small furrows; palpi short and stout, truncate at apex; mentum with a long, narrow, sharp median tooth, lateral lobes a little longer. Elytral spots oblong and covers intervals 2-7.

The above description is after Louwerens (1949).

Remarks. This species is similar to M. binotatus, but the former is smaller in size and has the sides of elytra gently rounded behind, in contrast to the larger size and more sharply rounded hind region of elytra in $M$. macromaculatus.

Distribution. Indonesia (Java). 
Macrocheilus gigas Zhao \& Tian, 2010

http://species-id.net/wiki/Macrocheilus_gigas

Fig. 50

Macrocheilus gigas Zhao \& Tian, 2010: 8. Type Locality: China (Guangdong), deposited in SCAU.

Remarks. $M$. gigas is similar to $M$. parvimaculatus and M. tripustulatus in having anterior seta of the labrum on the apical margin and the ligula thickened at apex which distinguishes these three species from other species with two spots on each elytron. But M. gigas differs from the other two species by wide apex of labrum and having median tooth of mentum sinuate near apex on lateral margin.

Materials examined. 1 male, the holotype, Guangdong: Zhanjiang, Jun.1983, deposited in SCAU; 1 male, Guangdong: Zhanjiang, Oct.1982, Zhichang Tan leg., deposited in SCAU; 2 males, Guangdong: Zhanjiang, July 1982, deposited in SCAU and MNHN.

Distribution. China (Guangdong: Zhanjiang).

Macrocheilus parvimaculatus Zhao \& Tian, 2010

http://species-id.net/wiki/Macrocheilus_parvimaculatus

Fig. 51

Macrocheilus parvimaculatus Zhao \& Tian, 2010: 9. Type Locality: China (Guangxi), deposited in SCAU.

Remarks. This species is easily distinguished from other species of Macrocheilus by its strongly convex labrum, maxillary palpomere 4 dilated in apical half and with small spots on elytra.

Materials examined. 1 male, the holotype, Guangxi: Liuzhou: Luzhai, 26 May 1980, Shaozhou Ruan leg.; 1 male, same data as holotype. All specimens deposited in SCAU.

Distribution. China (Guangxi).

\section{Macrocheilus tripustulatus (Dejean, 1825)}

http://species-id.net/wiki/Macrocheilus_tripustulatus

Figs 6, 14, 22, 31, 32, 41, 52

Helluo tripustulatus Dejean, 1825: 286 (syn. in Reiche, 1842: 334). Reiche, 1842: 334;

Chaudoir, 1872: 212; Heller, 1900: 3; Andrewes, 1919: 124; Andrewes, 1920: 501; Csiki, 1932: 1575; Lorenz, 2005: 512. Type locality: Indonesia (Java), deposited in MNHN.

Diagnosis. Length $12.0-12.5 \mathrm{~mm}$, width $4.0-4.3 \mathrm{~mm}$. Labrum (Fig. 6) strongly convex on anterior part, rounded and pointed in front, front seta on apical margin, intermediate one on upper surface close to margin; mandibles sharp at apex; mentum (Fig. 
14) irregular and densely setose, both tooth and lobes stout, tooth shorter than lobes, densely setose at basal half; palpi slender, palpomere 4 (Fig. 22) not dilated, densely setose, rounded and truncate at apex, labial palpomere 3 not dilated, bisetose inside; ligula strongly thickened and dilated, deeply depressed at sides, apex rounded, slightly emarginate in middle with a seta on either side. Elytra with two pairs of spots, front spot rounded, covering intervals 3-7 in the middle, hind spot close to apical inner angles, nearly rectangular, covering intervals $1-5$; apex roundly truncate.

Male genitalia. Median lobe dilated in the middle ventrally, apical lamella long, wide and round at apex (Figs 31-32).

Female genitalia: Gonocoxite slender, setose on ventral surface, three setae on dorsal side, apex sharp (Fig. 41).

Remarks. $M$. tripustulatus can be distinguished from $M$. parvimaculatus by the slender maxillary palpomere 4, greater convexity of labrum and larger elytral spots.

Materials examined. 1 female, the holotype, "tripustulatus Dejean (non Fabr.), Java, Coll. Dejean, 3-pustulatus Wiedemann (Helluo). Fabr. (Brachinus), Western, ExMusaeo Chaudoir"; 1 male, "Java merid., 1500, 1891, H. Fruhstorfer."; 1 male, “ Java”, "Ex-Musaeo Mniszech”; 1 female, "Carin Chebà, 900-1100 m, L. Fea, V Xii-88; Ex-Musaeo H.W.Bates 1892". All specimens deposited in MNHN.

Distribution. Myanmar and Indonesia (Java).

\section{Macrocheilus chaudoiri Andrewes, 1919}

http://species-id.net/wiki/Macrocheilus_chaudoiri

Fig. 53

Macrocheilus chaudoiri Andrewes, 1919: 130; 1920: 502; 1924: 470; 1930: 207; Csiki, 1932: 1573; Jedlička, 1963: 470; Lorenz, 2005: 512; Zhao \& Tian, 2010: 11. Type Locality: India, deposited in MNHN.

Acanthogenius trimaculatus sensu Chaudoir, 1872: 171 (non Oliver). Type Locality: India (Decan), deposited in MNHN.

Macrocheilus ruficollis Heller, 1923: 296; Andrewes, 1926: 258. Type Locality: Philippines (Luzon), deposited in MDSG.

Remarks. M. chaudoiri, M. nigrotibialis, $M$. bensoni and $M$. deuvie are similar in having the anterior seta of the labrum beneath the apex and two pairs of elytral spots. This species is distinct from the other three species in having the head and pronotum reddish brown and maxillary palpomere 4 strongly dilated.

Materials examined. 1 female, the holotype, "Ex-Musaeo Chaudoir; Macrocheilus Chaudoiri Andr., H.S. Andrewes det.; 3-maculatus Chaud., Deccan, Coll. Jeakes" (MNHN); 1 male, "Maissour, Sakrabail, IX 1897" (MNHN); 1 female, "Museum Paris, Cochinchine, Harmand 1872" (MNHN); 1 female, "Java" and "Museum Paris, Lakhon, Harmand 1878” (MNHN); 1 female, "Insl. Phiip.” and “Thorey” (MNHN).

Distribution. China (Macao), Cambodia, Laos, Vietnam, the Philippines, Indonesia (Sumatra) and India. 


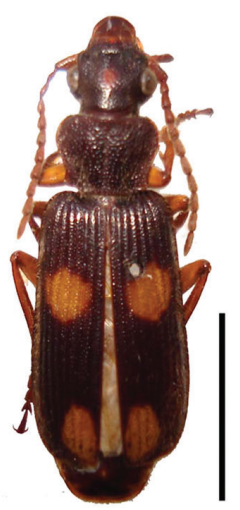

52

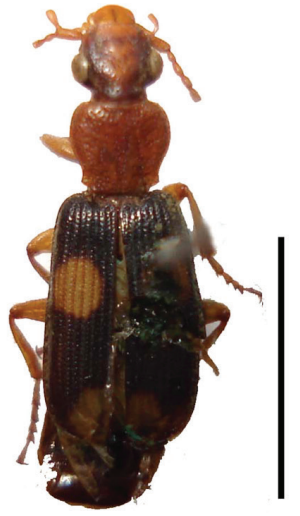

53

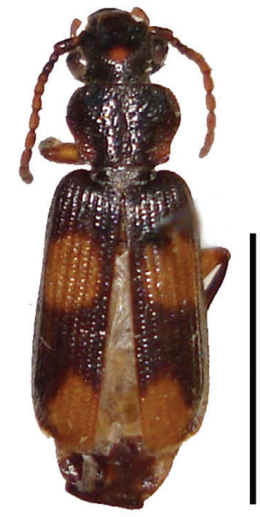

54

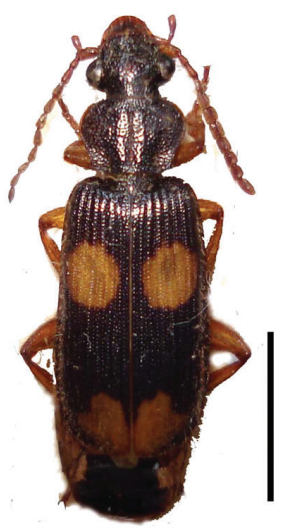

55
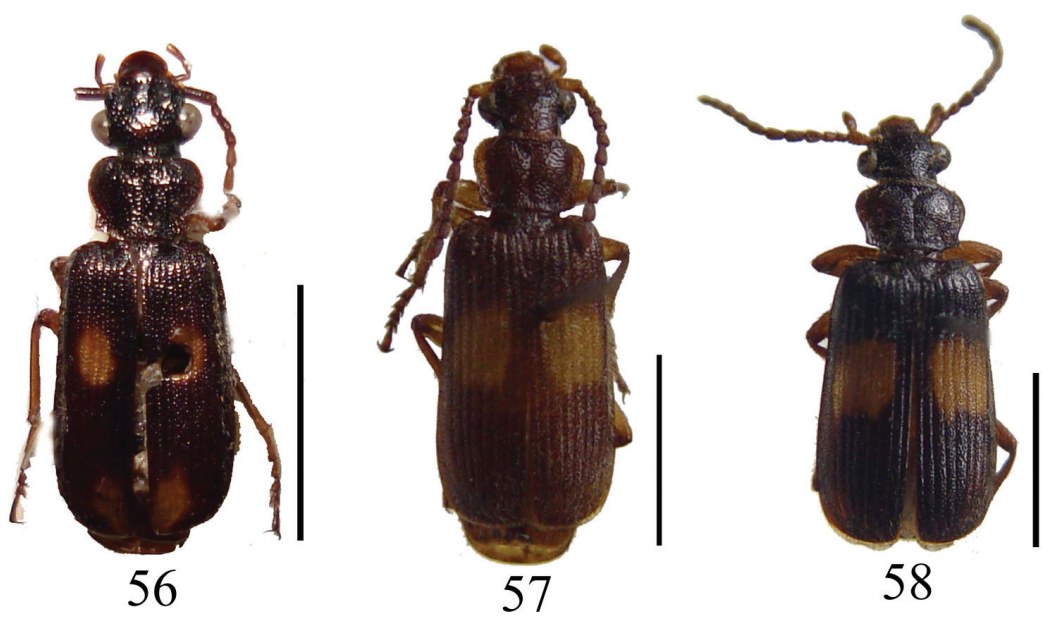

58
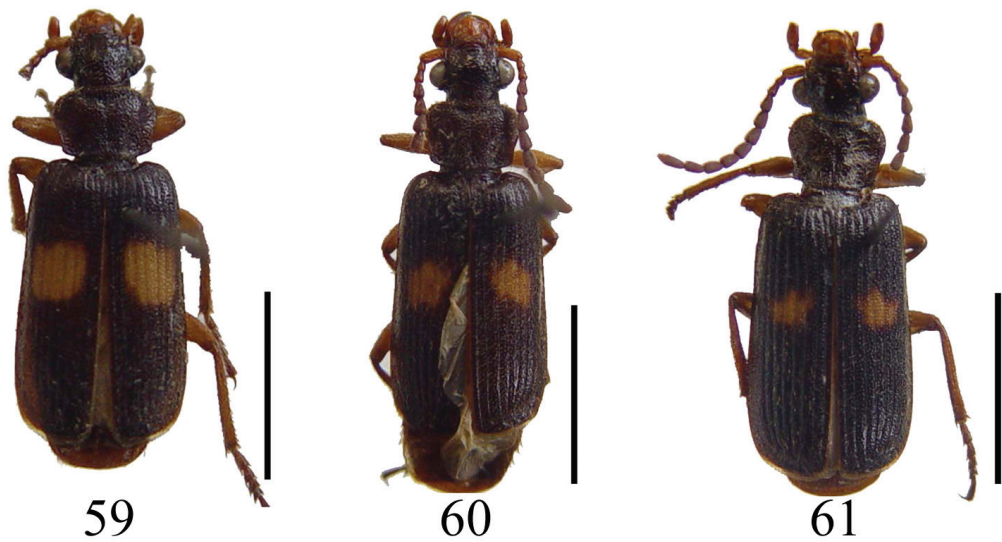

Figure 52-6I.52 M. tripustulatus (holotype) $53 \mathrm{M}$. chaudoiri (holotype) $54 \mathrm{M}$. nigrotibialis (holotype) 55 M. bensoni (male) 56 M. deuvie (holotype) 57 M. fuscipennis (holotype) 58 M. solidipalpis (holotype) 59 M. cheni (holotype) 60 M. quadratus (holotype) 6I M. sinuatilabris (holotype). Scale bar: $5.0 \mathrm{~mm}$. 


\section{Macrocheilus nigrotibialis Heller, 1900}

http://species-id.net/wiki/Macrocheilus_nigrotibialis

Figs $7,15,23,33,34,42,54$

Macrochilus nigrotibialis Heller, 1900: 2. Andrewes, 1920: 497; Csiki, 1932: 1574; Lorenz, 2005: 512. Type locality: Indonesia (Sulawesi), deposited in MDSG.

Diagnosis. Length $8.0-10.1 \mathrm{~mm}$, width $3.0-3.5 \mathrm{~mm}$. Labrum (Fig. 7) convex, arcuate at apex, front setae beneath apex, intermediate one on apical margin, hind one close to middle margin; mandibles sharp at apex; mentum (Fig. 15) setose at base; median tooth triangular and shorter than lobes, with two pairs of setae at base; lobes obtuse at apex; maxillary palpomere 4 (Fig. 23) roundly dilated, labial palpomere 4 triangular in shape and dilated, 3 not dilated and bisetose on inner sides; ligula thickened, apical margin arcuate inwards, deeply depressed at sides, with a median impression close to apex, outer apical angles rounded, with a seta on either of median impression close to apex. Elytra with front spot large, just before middle, almost rounded, covering intervals 3-7 and extended to small part of 2 and 8; hind spot on inner angles, more or less triangular, covering intervals 1-5.

Male genitalia. Median lobe slender, apical lamella round (Figs 33-34).

Female genitalia. Gonocoxite slender, arcuate, with three or four setae on dorsal side, apex slightly obtuse (Fig. 42).

Remarks. This species differs from following two species in having the tibiae black, maxillary palpomere 4 more dilated, the median lobe of male genitalia stouter and the apical lamella more rounded.

Materials examined. 1 male, the holotype, "typus!", "Drs. Sarasin N. Celebes Panot-Maimang", "12623", "Staatl. Museum fur Tierkunde. Dresden”, deposited in SNSD. 1 female, labeled "Nord Borneo Mont Kina Balu 5-8, 1903, John Waterstradt; Macrochilus nigrotibialis Heller, det. Andrewes", deposited in MNHN.

Distribution. Indonesia (Sumatra, Malaysia and Sulawesi).

\section{Macrocheilus bensoni Hope, 1838}

http://species-id.net/wiki/Macrocheilus_bensoni

Fig. 55

Macrocheilus bensoni Hope, 1838: 166; Chaudoir, 1872: 212; Bates, 1892: 389; Heller, 1900: 3; Andrewes, 1919: 176, 202; Hůrka, 2003: 407; Lorenz, 2005: 512: Zhao \& Tian, 2010: 10. Type locality: India, deposited in NHML.

Carabus trimaculatus Olivier, 1790: 347 (non Villers, 1789); Andrewes, 1919: 129, 176; 1920: 502; 1930, 208; Csiki, 1932: 1574; Wu, 1937: 188; Jedlička, 1963: 470. Type locality: China, deposited in NHML.

Helluo quadrimaculata Guérin-Méneville, 1840: 38; Chaudoir, 1872: 212. Type locality: India, deposited in MNHN. 
Helluo tripustulata sensu Guérin-Méneville, 1843: 34 (non Dejean, 1825); Andrewes, 1923: 460. Type locality: China, deposited in MNHN.

Macrocheilus quadripustulatus Schmidt-Göbel, 1846: 65. Type locality: Myanmar, deposited in NMP.

Acanthogenius infuscatus Bates 1892, 389; Andrewes, 1920: 493. Type locality: Myanmar (Bhamo), deposited in MGI.

Remarks. This species can be distinguished from $M$. chaudoiri by the black head and pronotum and from $M$. nigrobibialis by the slender maxillary palpomere 4 .

Materials examined. 1 male, "North China, 1884, Janson" (MNHN); 1 male, "North India, Coll. Benson, Ex-Musaeo H.W. Bates, 1892" (MNHN); 1 male, "Ind. Angl., Coimbatore Dt, Siruveni, VI. 1937" (MNHN); 1 female, "Ind. Angl., Mysore" (MNHN); 1 male, "Guangdong: Zhanjiang, Oct.1982, Zhichang Tan leg." (SCAU); 2 males, "Guangdong: Yingde, 27 Mar.2003, Danyang Zhao leg." (SCAU and MNHN); 1 male, Guangxi, Dec.1983" (SCAU); 1 male, "Yunnan: Jinghong, Jul. 1985" (SCAU); 1 female, "Hainan: Diaoluoshan, 26 Nov.1963" (SCAU).

Distribution. China (Fujian, Jiangxi, Guangdong, Guangxi, Guizhou, Yunnan, Hongkong, Hainan), Laos, Vietnam, Myanmar, India and Sri Lanka.

\section{Macrocheilus deuvie sp. $\mathbf{n}$.}

urn:lsid:zoobank.org:act:0181841F-FB7C-4A7D-9612-AB0BFEAD91F3

http://species-id.net/wiki/Macrocheilus_deuvie

Figs $8,16,24,35,36,56$

Description. Length $9.5 \mathrm{~mm}$, width $3.5 \mathrm{~mm}$.

Black; ligula, antennomeres $1-4$, a spot on vertex, lateral margin of pronotum and legs reddish brown; sides of ligula, palpi, antennomeres 5-11 and elytral spots brown.

Head convex; neck short and punctate on dorsal surface; frontoclypeal sulcus faint, frontal foveae short and shallow; clypeus with apical margin truncate, two setae on each side of apical outer angels, a row of 6 setae along apical margin, irregularly setose basally on each side; labrum (Fig. 8) convex anteriorly, apical margin rounded, front setae beneath near apex, middle one just on apical margin, hind one close to middle margin; mandibles covered by labrum, sharp at apex; mentum (Fig. 16) irregularly setose and punctate at base, median tooth triangular and shorter than lobes, with a pair of setae at base, lobes obtuse at apex; maxillary palpi (Fig. 24) not dilated, labial palpomere 3 with two setae on inner side; ligula thickened, apex deeply and widely emarginated in middle.

Pronotum flat; widest before middle; faint median line, median and apical impression distinct, basal foveae deep; lateral margin round in front, strongly sinuate near base; hind angles nearly rectangular, with a small obtuse tooth and an emargination before tooth. 
Elytra flat, striae with large, close punctures and setae; intervals convex, with two rows of regular punctures and setae, interval 8 wider than others and densely and irregularly punctate and setose; spots small, front spot rounded, just before middle, covering intervals 3-6, hind spot rhombic, on inner apical angles, covering intervals 1-5.

Male genitalia. Median lobe dilated in middle on ventral margin; apical lamella elongated, rounded at apex (Figs 35-36).

Remarks. This species is very similar to M. bensoni, but differs by it's smaller size, curved labrum at anterior part, clypeus glabrous on middle, pronotum with lateral margin strongly sinuate near base, and male genitalia dilated on ventral margin.

Type material. 1 male, the holotype, "Philippines, Bohol. Ch. Semper", deposited in MNHN.

Etymology. This species is named in honor of Dr. Thierry Deuve (MNHN), a well known carabidologist.

Distribution. The Philippines.

\section{Macrocheilus fuscipennis Zhao \& Tian, 2010}

http://species-id.net/wiki/Macrocheilus_fuscipennis

Fig. 57

Macrocheilus fuscipennis Zhao \& Tian, 2010: 12. Type locality: China (Guangxi), deposited in SCAU.

Remarks. This species is similar to M. solidipalpis and M. cheni in having the larger elytral spots, but easily distinguishable from them by the labrum without additional setae, mandibles obtuse at apex, median tooth of mentum with lateral margin not sinuate and body brownish.

Materials examined. 1 male, the holotype, "Guangxi: Napo, 10 Oct.1970, by light trap".

Distribution. China (Guangxi: Napo).

\section{Macrocheilus solidipalpis Zhao \& Tian, 2010}

http://species-id.net/wiki/Macrocheilus_solidipalpis

Fig. 58

Macrocheilus solidipalpis Zhao \& Tian, 2010: 13. Type locality: China (Guangxi), deposited in SCAU.

Remarks. This species is similar to $M$. cheni but easily distinguishable from the latter by the presence of additional setae between the anterior and anterior setae, the median tooth of the mentum with sinuate lateral margins in middle (sinuate on api- 
cal one-third in $M$. cheni), the median lobe larger, and the apical lamella long and narrowed towards apex.

Materials examined. 1 male, the holotype, "Guangxi: Dibei, Oct.1980, Xiuzhen Mao leg., by light trap".

Distribution. China (Guangxi: Dibei).

\section{Macrocheilus cheni Zhao \& Tian, 2010}

http://species-id.net/wiki/Macrocheilus_cheni

Fig. 59

Macrocheilus cheni Zhao \& Tian, 2010: 14. Type locality: China (Guangxi), deposited in SCAU.

Remarks. This species is similar to M. solidipalpis and the differences from the latter were mentioned above.

Materials examined. 1 male, the holotype,"Guangxi: Tengxian, Oct.1980”.

Distribution. China (Guangxi: Tengxian).

\section{Macrocheilus quadratus Zhao \& Tian, 2010}

http://species-id.net/wiki/Macrocheilus_quadratus

Fig. 60

Macrocheilus quadratus Zhao \& Tian, 2010: 16. Type locality: China (Guangxi), deposited in SCAU.

Remarks. This species is easily distinguished from other species by the shape of pronotum.

Materials examined. 1 male, the holotype, labeled "Guangxi: Cangwu, 1980, in paddy field".

Distribution. China (Guangxi: Cangwu).

\section{Macrocheilus sinuatilabris Zhao \& Tian, 2010}

http://species-id.net/wiki/Macrocheilus_sinuatilabris

Fig. 61

Macrocheilus sinuatilabris Zhao \& Tian, 2010: 17. Type locality: China (Guangxi), deposited in SCAU.

Remarks. M. sinuatilabris is similar to M. quadratus in having three pairs of setae on the labrum and small elytral spots. However, it differs from $M$. quadratus in having 
smaller elytral spots, the median tooth of the mentum obtuse at its apex, the rounded apex of the labrum, the close positioning of front and intermediate labral setae, and the slender median lobe of the aedeagus.

Materials examined. 1 male, the holotype, labeled "Guangxi: Fenghuangcheng, Sep.1981, by light trap".

Distribution. China (Guangxi: Fenghuangcheng).

\section{Distribution of Macrocheilus in the Oriental Region}

The zoogeographical pattern of Macrocheilus is illustrated in Figure 62. Most species are distributed in limited small areas, but three are widespread, occurring in many countries: $M$. asteriscus in China, Vietnam, Laos, Myanmar, Indonesia and India; $M$. chaudoiri in China, Cambodia, Laos, Vietnam, the Philippines, Sumatra and India; and M. bensoni in China, Laos, Vietnam, Myanmar, India and Sri Lanka. At present the Macrocheilus faunas of Thailand and Nepal remain unknown.

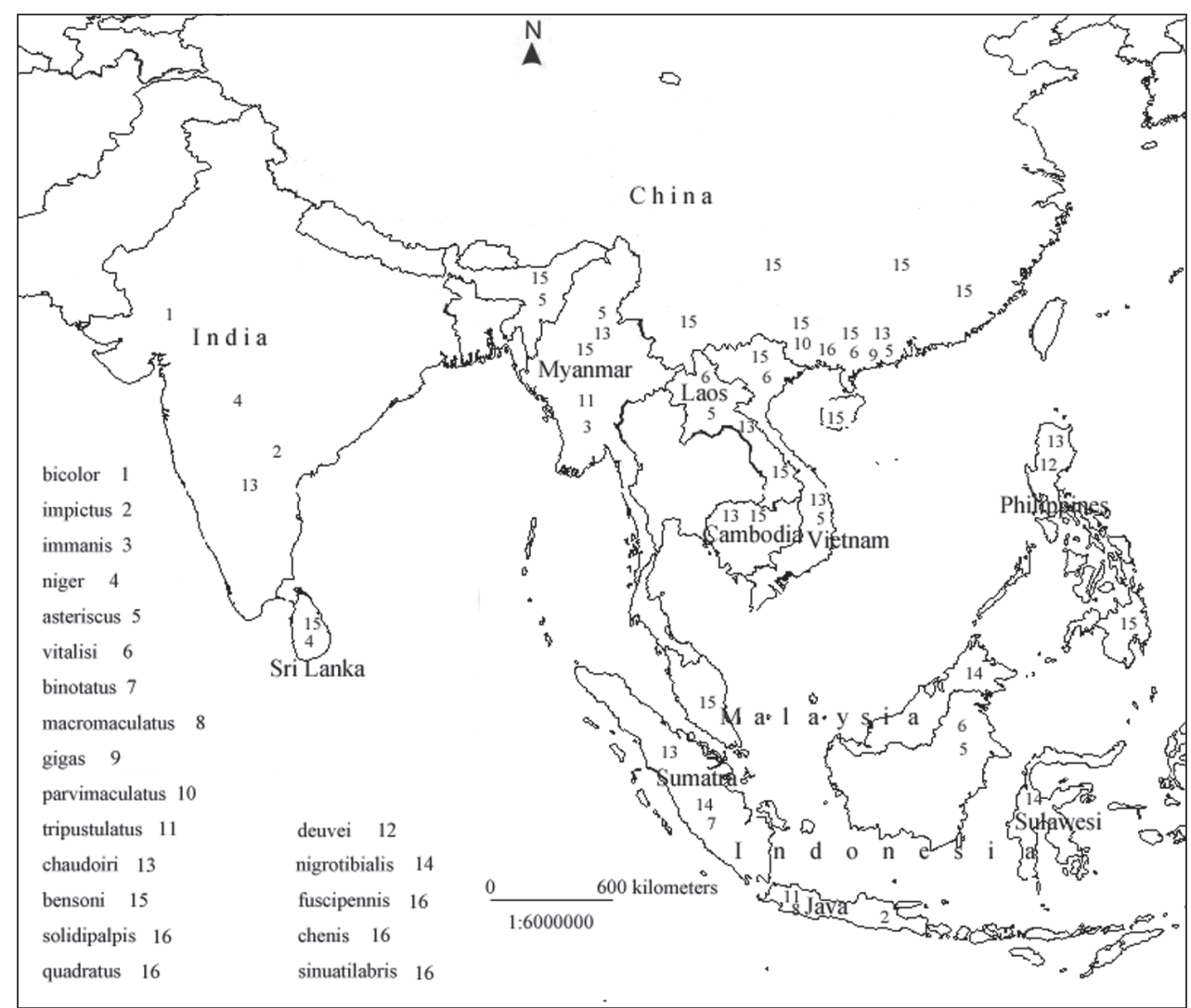

Figure 62. Distribution map of Macrocheilus in the Oriental Region. 


\section{Acknowledgements}

We express our deep gratitude to Dr. Thierry Deuve and Ms. Azadeh Taghavian (MNHN), Ms. Christine Taylor (NHML) and Dr. Olaf Jaeger (SNSD) for the providing material examined in this study. In particular, the first author thanks Dr. Thierry Deuve for his guidance and for providing equipment and help in borrowing type specimens during the period when she studied at MNHN. His constructive suggestions and comments also have been very helpful for improving the manuscript. We also thank Dr. Thomas K. SABU (St. Joseph's College, Devagiri, Calicut, Kerala) for correction to the text. This study was sponsored partly by the National Natural Science Foundation of China (No. 30670249) and by Guangdong Forestry Science and Technology Innovation (No. 2011KJCX027).

\section{References}

Andrewes HE (1919) On the types of Oriental Carabidae in the British Museum, and in the Hope Department of the Oxford University Museum. The transactions of the Entomological Society of London, 1919: 119-217.

Andrewes HE (1920) Papers on Oriental Carabidae.-V. The Annals and Magazine of Natural History, 9 (6): 493-506. doi: 10.1080/00222932008632476

Andrewes HE (1921) Notes on Synonymy and on some types of Oriental Carabidae in various foreign collections. The Transactions of the Entomological Society of London, 1921: 145-195.

Andrewes HE (1923) On the Oriental Carabidae of the "Reise Novara". The Transactions of the Entomological Society of London, 1923: 459-468.

Andrewes HE (1924) Part 2: Systematic list and description of a new species. In: Andrewes H.E. $\&$ Scott H.: A list of Carabidae from Macao, South China, with a description of a new species and biological notes. The Annals and Magazine of Natural History, 9 (13): 466-472. doi: $10.1080 / 00222932408633058$

Andrewes HE (1926) Papers on Oriental Carabidae.-XVI. The Annals and Magazine of Natural History, 9(17): 252-259. doi: 10.1080/00222932608633402

Andrewes HE (1930) Catalogue of Indian Insects (Part 18: Carabidae). Government of India Central Publication Branch, Calcutta, xxi+389 pp.

Andrewes HE (1931) Some keys to Sumatran Carabidae, together with descriptions of further new species. Zoologische Medemeelingen uitgegeven door s'Rijks Museum van Natuurlijke Historie te Leiden, 14: 54-78.

Bates HW (1892) Viaggio de Leonardo Fea in Birmania e regioni vicine. XLIV. List of the Carabidae. Annali del Museo Civico di Storia Naturale di Genova, 32: 267-428.

Chaudoir M de (1872) Descriptions d'espèces nouvelles de Carabiques de la tribu des Troncatipennes, et remarques synonymiques. Revue et Magasin de Zoologie pure et appliquée, (2) 23: 138-143, 168-172, 212-221.

Csiki E (1932) Carabidae: Harpalinae VII (Pars 124). In Junk W, Schenkling S (Eds) Coleopterorum Catalogus. Volumen III. Carabidae III. Berlin, 1279-1598. 
Dejean PFMA (1825) Species général des Coléoptères de la collection de M. le comte Dejean. Tome premier. Chez Crevot, Libraire-Editeur, Paris, 463 pp.

Guérin-Méneville FE (1840) Coléoptères nouveaux du Plateau des Neelgherries dans les Indes Orientales, découvertes par M. Adolphe Delessert. Revue Zoologique, 37-42.

Guérin-Méneville FE (1843) Animaux articulés. In : Delessert A.: Souvenirs d'un voyage dans l'Inde exécuté de 1834 à 1839. Paris: Fortin, Masson \& Co, 33-98 + pl. 11-27.

Heller KM (1900) Neue Käfer von Celebes. IV. (Nr. 5). Abhandlungen und Berichte des Königlichen Zoologischen und Anthropologishe-Ethnographischen Museums zu Dresden, 9: $1-46$.

Heller KM (1923) Some new Malayan Carabidae, especially Philippine. The Philippine Journal of Science, 23: 295-307.

Hope FW (1838) The coleopterist's manual, part the second, containing the predaceous land and water beetles of Linneus and Fabricius. London: Bohn, xvi+ 168, 3 pl., frontispiece.

Hůrka K (2003) Carabidae: Helluonini. In: Löbl I, Smetana A (Eds) Catalogue of Palaearctic Coleoptera. I: Archostemata-Myxophaga-Adephage. Apollo Books, Stenstrup, 407 pp.

Jeannel R (1949) Faune de l'Empire français. XI. Coléoptères Carabiques de la région Malgache (troisième partie). Paris: Librairie Larose, 767-1146.

Jedlička A (1963) Monographie der Truncatipennen aus Ostasien. Lebinnae - Odacanthinae - Brachyninae (Coleoptera, Carabidae). Entomologische Abhandlungen und Berichte aus dem Staatlchen Museum für Tierkunde in Dresden, 28: 269-578.

Lindroth CH (1974) Coleoptera Carabidae. Handbooks for the Identification of British Insects. London: Published by the Society and Sold at its Rooms, 148 pp.

Lorenz W (2005) Systematic List of Extant Ground Beetles of the World. Second Edition. Tutzing: Published by the author, $530 \mathrm{pp}$.

Louwerens CJ (1949) Some notes on the Carabidae, collected by Mr. P. H. van Doesburg in the Malay Archipelago with descriptions of new species. Tijdschrift voor Entomologie uitgegeven door de Nederlandsche Entomologische Vereeniging, 90: 45-53.

Park JK, Trac DH, Will K (2006) Carabidae from Vietnam. Journal of Asia-Pacific Entomology, 9(2): 85-105. doi: 10.1016/S1226-8615(08)60280-0

Olivier AG (1790) Encyclopédie méthodique, ou par ordre de matières; par une société de gens de lettres, de savans et d'artistes; précédée d'un vocabulaire universel, servant de table pour tout l'ouvrage, ornée des portraits de Mm. Diderot \& d'Alembert, premiers éditeurs de l'Encyclopédie. Histoire naturelle. Insectes. Tome cinquième. Livraison 41. Paris: C.J. Panckouche, 368 pp.

Reichardt H (1974) Monograph of the Neotropical Helluonini, with notes and discussions on Old World forms (Coleoptera: Carabidae). Studia Entomologia, 17: 211-302.

Redtenbacher L (1867) Zoologischer Theil. Zweiter Band. I. Abtheilung A. 1. Coleoptera. Reise der Österreichischen Fregatte Novara un die Erde in den Jahren 1857, 1858, 1859 unter der befehlen des Commodere B. von Wüllerstorf-Urbair. Karl Gerold's Sohn, Wien, 1-249.

Reiche L (1842) Recherches sur les Helluonides, ou révision du genre Helluo, Bonelli et Dejean. Annales de la Société Entomologique de France, 11[1842]: 323-344.

Schmidt-Göbel HM (1846) Faunula Coleopterorum Birmaniae, Adjectis Nonnulis Bengaliae Indigenis, Prague: Gottlieb Hasse Söhne, viii+ $94+3$ pls 
White A (1844) Some new insects from China. The Annals and Magazine of Natural History, 14: 422-423. doi: 10.1080/037454809495213

Wu CF (1937) Catalogus Insectorum Sinensium. III. Peiping: The Fan Memorial Institute of Biology, 1312 pp.

Zhao DY, Tian MY (2010) A review of the genus Macrocheilus Hope (Coleoptera: Carabidae: Helluonini) of China, with descriptions of seven new species. Polish Journal of Entomology, 29: 3-23. 